\title{
HUBUNGAN MEAN ARTERIAL PRESSURE DENGAN KEJADIAN MUAL MUNTAH PASCA OPERASI PADA PASIEN POST ANESTESI SPINAL DI RUMAH SAKIT BHAYANGKARA
}

\author{
The Correlation Of Mean Arterial Pressure With Post Operative Nausea Vomiting \\ in Post Spinal Anesthesia In Bhayangkara Hospital
}

\author{
$\underline{\text { Nonok Karlina }}$ \\ Program Studi Ilmu Keperawatan, STIKes Mahardika Cirebon \\ e-mail:nonok.karlina@gmail.com
}

\begin{abstract}
Nausea and vomiting are the most common complications after surgery with anesthesia. The incidence of nausea and vomiting of all patients undergoing surgery occurs in $30 \%$ of patients to $70 \%$ in hospitalized patients that arise within the first 24 hours. Spinal anesthesia techniques have disadvantages such as bradycardia, apnea, inadequate breathing, nausea / nausea and vomiting, headache after lumbar puncture, high or total spinal block, hypotension. Hypotension is one of the causes of nausea and vomiting in spinal anesthesia.

The purpose of this study was to determine the relationship of mean arterial pressure with postoperative nausea and vomiting in post spinal anesthesia patients.

The method in this study uses the correlation description method with a cross-sectional approach. The study was conducted in Recovery Room of Bhayangkara Indramayu Hospital in June - July 2018. The study population was all postoperative spinal anesthesia patients in Recovery Room Bhayangkara Hospital with a sample of 30 people taken by simple random sampling technique. Data analysis using descriptive analysis and bivariate test using chi-square correlation test.

The results showed that the mean arterial pressure of the respondents were mostly in the high category (53.3\%), and most respondents experienced $63.3 \%$ postoperative nausea and vomiting events. Statistical test results showed $p$ value $=$ 0.003. This shows a relationship between mean arterial pressure and the incidence of postoperative nausea and vomiting in post-spinal anesthesia patients at Bahayangkara Hospital.

This study recommends the importance of nurses monitoring the blood pressure of post spinal anesthesia patients to reduce patient mortality.
\end{abstract}

Keywords: Mean Arterial Pressure, Postoperative Nausea Vomiting, Post Spinal Anesthesia

\section{PENDAHULUAN}

Pembedahan adalah tindakan pengobatan invasif melalui sayatan untuk membuka atau menampilkan bagian tubuh yang akan ditangani dan diakhiri dengan penutupan dan penjahitan luka (Sjamsuhidajat, 2010). Sedangkan tindakan anestesi adalah usaha untuk menghilangkan seluruh modalitas dari sensasi nyeri, rabaan, suhu, posisi yang meliputi pra, intra, dan post anestesi (Pramono, 2015).

Jenis tindakan anestesi yaitu dengan general dan regional anestesi. Spinal anestesi termasuk kedalam regional anestesi yaitu dengan cara menyuntikan anestetik lokal pada ruang subaraknoid dan menghasilkan blokade nyeri. Blokade yang dilakukan pada segmen vertebra

\section{METODE PENELITIAN}

Desain penelitian ini adalah deskriptif dengan pendekatan cross sectional. Penelitian ini dilakukan di Ruang Recovery RS Bhayangkara pada bulan Juni-Juli 2018. Populasi penelitian ini adalah seluruh pasien post operasi anestesi spinal di Ruang Recovery Rumah Sakit Bhayangkara dengan jumlah sampel sebanyak 30 orangmenggunakan teknik simpel random sampling.

Variabel bebas dalam penelitian ini adalah mean arterial pressure yang diperoleh melalui pengukuran langsung menggunakan alat spighnomanometer sedangkan sebagai variabel terikat adalah kejadian mual muntah pasca operasi yang diperoleh melalui observasi dengan menggunakan Numeric Rating Scale (NRS). Teknik 
lumbal 3-4 menghasilkan anestesi di daerah pusar ke bawah karena konsentrasi yang lebih besar pada daerah lumbosakralis dan sacrum karena pengaruh gaya gravitasi, dan mempengaruhi nervus bagian atas akan lebih sedikit menerima obat anestesi, yang mengakibatkan venus return ke jantung meningkat sebagaimana darah ektermitas bawah diredistribusi ke jantung peningkatan inisial (awal) pada cardiac output dan tekanan darah arteri serta meningkatkan parasimpatik yang mengimpuls terhadap nodus sinoatrial dan miocardium, maka akan terjadi hipotensi dan penurunan cardiac output (Birnbach, 2010).

Menurut Majid (2011), teknik anestesi spinal memiliki kekurangan seperti terjadinya hipotensi, bradikardi, apnoe, pernafasan tidak adekuat, nausea/mual dan muntah, pusing kepala pasca pungsi lumbal, blok spinal tinggi atau spinal total. Mual muntah merupakan komplikasi yang sering terjadi akibat spinal anestesi, dengan angka kejadian 20-40\% (Keat, 2012).

Hipotensi, hipoksia, kecemasan atau faktor psikologis, pemberian narkotik sebagai premedikasi, puasa yang tidak cukup serta adanya rangsangan visceral oleh operator merupakan beberapa hal penyebab mekanisme terjadinya mual muntah pada spinal anestesi. Hipotensi akan menyebabkan terjadinya hipoksemia dan hipoperfusi di chemoreseptor trigger zone (CTZ) sebagai pusat rangsang muntah (Mulroy, 2009).

Hipotensi dapat dilakukan dengan pengukuran tekanan sistol dan diastole, penentuan hipotensi pasca anestesi spinal menggunakan perhitungan Mean Arterial Pressure. Mean Arterial Pressure merupakan tekanan ratarata yang mengalirkan darah masuk ke dalam jaringan sepanjang siklus jantung. Mean Arterial Pressure $<70$ $\mathrm{mmHg}$ dapat dikategorikan sebagai kondisi hipotensi (Georg, 2015; Kundu, 2017).

Tujuan dari penelitian ini adalah untuk mengetahui "Hubunganmean arterial pressure dengan kejadian mual muntah pasca operasi pada pasien post anestesi spinal di Ruang Recovery RS Bhayangkara”.

\section{METODE PENELITIAN}

Desain penelitian ini adalah deskriptif dengan pendekatan cross sectional. Penelitian ini dilakukan di Ruang Recovery RS Bhayangkara pada bulan Juni-Juli 2018. Populasi penelitian ini adalah seluruh pasien post operasi anestesi spinal di Ruang Recovery Rumah Sakit Bhayangkara dengan jumlah sampel sebanyak 30 orangmenggunakan teknik simpel random sampling.

Variabel bebas dalam penelitian ini adalah mean arterial pressure yang diperoleh melalui pengukuran langsung menggunakan alat spighnomanometer sedangkan sebagai variabel terikat adalah kejadian mual muntah pasca operasi yang diperoleh melalui observasi dengan menggunakan Numeric Rating Scale (NRS). Teknik analisis data menggunakan uji statistik chi square

\section{HASIL DAN PEMBAHASAN}

1. Mean Arterial Pressure

Tabel. 1

Distribusi Frekuensi

Berdasarkan Mean Arterial Pressure

\begin{tabular}{|c|l|c|l|}
\hline No. & $\begin{array}{l}\text { Mean } \\
\text { Arterial } \\
\text { Pressure }\end{array}$ & $\begin{array}{c}\text { Frekuensi } \\
(\mathbf{F})\end{array}$ & $\begin{array}{c}\text { Persentase } \\
(\mathbf{\%})\end{array}$ \\
\hline 1 & Rendah & 9 & 30 \\
\hline 2 & Normal & 5 & 16,7 \\
\hline 3 & Tinggi & 16 & 53,3 \\
\hline \multicolumn{2}{|c|}{ Total } & 30 & 100 \\
\hline
\end{tabular}

Hasil penelitian menunjukkan bahwa mean arterial pressure sebagian besar pada kategori tinggi sebanyak 16 responden $(53,3 \%), 9$ responden pada kategori rendah (30\%) dan 5 responden pada kategori normal $(16,7 \%)$.

2. Kejadian Mual Muntah Pasca Operasi

Tabel. 2

Distribusi Frekuensi

Berdasarkan Kejadian Mual Muntah Pasca Operasi

\begin{tabular}{|c|l|c|c|}
\hline No. & $\begin{array}{l}\text { Mean } \\
\text { Arterial } \\
\text { Pressure }\end{array}$ & $\begin{array}{c}\text { Frekuensi } \\
(\mathbf{F})\end{array}$ & $\begin{array}{c}\text { Persentase } \\
(\mathbf{\%})\end{array}$ \\
\hline 1 & Ada & 19 & 63,3 \\
\hline 2 & Tidak Ada & 11 & 36,7 \\
\hline \multicolumn{2}{|c|}{ Total } & 30 & 100 \\
\hline
\end{tabular}

Hasil penelitian menunjukkan bahwa sebagian besar responden mengalami kejadian mual muntah pasca operasi yaitu sebanyak 19 responden 63,3\%, dan 11 responden tidak mengalami kejadian mual muntah pasca operasi sebanyak $36,7 \%$.

3. Analisis hubungan mean arterial pressure dengan kejadian mual muntah pasca operasi pada pasien post anestesi spinal

Tabel. 3

Hubungan Mean Arterial Pressure Dengan Kejadian Mual Muntah Pasca Operasi pada Pasien Post Anestesi Spinal

\begin{tabular}{|c|c|c|c|c|c|c|c|}
\hline \multirow{3}{*}{$\begin{array}{c}\text { Mean } \\
\text { Arterial } \\
\text { Preassure }\end{array}$} & \multicolumn{4}{|c|}{$\begin{array}{c}\text { Kejadian Mual } \\
\text { Muntah }\end{array}$} & \multirow{2}{*}{\multicolumn{2}{|c|}{ Total }} & \multirow{2}{*}{$\begin{array}{c}P \\
\text { value }\end{array}$} \\
\hline & \multicolumn{2}{|c|}{ ada } & \multicolumn{2}{|c|}{$\begin{array}{c}\text { Tidak } \\
\text { Ada }\end{array}$} & & & \\
\hline & $\mathrm{n}$ & $\%$ & $\mathrm{n}$ & $\%$ & $\mathrm{n}$ & $\%$ & 0,003 \\
\hline Rendah & 8 & 88,8 & 1 & 11,1 & 9 & 100 & \\
\hline Normal & 0 & 0 & 5 & 100 & 5 & 100 & \\
\hline Tinggi & 11 & 68,8 & 5 & 31,3 & 16 & & \\
\hline Total & 19 & 3,36 & 11 & 36,7 & 30 & 100 & \\
\hline
\end{tabular}

Berdasarkan tabel tersebut diperoleh $\mathrm{p}$-value $\leq \alpha(p$ value $=0,003 \alpha=0,05)$ yang menunjukkan bahwa Ho ditolak artinya ada hubungan antara mean arterial pressure dengan kejadian mual muntah pasca operasi pada pasien post anestesi spinal di Ruang Recovery RS Bhayangkara. 
Tindakan anestesi spinal yang biasa digunakan untuk operasi elektif perut bagian bawah banyak menimbulkan komplikasi, salah satu komplikasi yang sering terjadi adalah hipotensi. Hipotensi bila berlangsung lama dan tidak diterapi akan menyebabkan hipoksia jaringan dan organ dan bila keadaan ini berlanjut terus akan mengakibatkan keadaan syok hingga kematian (Birnbach, 2010).

Mual muntah merupakankomplikasi yang sering terjadiakibat spinal anestesi, dengan angka kejadian 20$40 \%$ (Keat, 2012). Hipotensi, hipoksia, kecemasan atau faktor psikologis, pemberian narkotik sebagai premedikasi, puasa yang tidak cukup serta adanya rangsangan visceral oleh operator merupakan beberapa hal penyebab mekanisme terjadinya mual muntah pada spinal anestesi.

Menurut Nileshwar (2014) mual dan muntah pasca operasi (Post Operative Nausea and Vomiting/ PONV) adalah mual dan muntah pasien yang diakibatkan setelah terjadinya pembedahan, mual muntah merupakan komplikasi yang sering terjadi selama anestesi. Sebanyak $30 \%$ dari 100 juta lebih pasien bedah di seluruh dunia mengalami PONV (Smith, 2012).

Hasil penelitian ini sejalan dengan penelitian yang dilakukan Novitasari tahun 2017 mengenai hubungan MAP dengan kejadian PONV pada pasien seksio sesarea dengan spinal anestesi di RSUD Sleman Yogyakarta yang dilakukan pada 48 responden. Hasil penelitian menunjukkan bahwa terdapat hubungan MAP dengan kejadian PONV pada pasien seksio sesarea dengan spinal anestesi di RSUD Sleman Yogyakarta dengan nila $\mathrm{p}$ Value sebesar 0,004 ( $\mathrm{p}<0,05)$, dengan keeratan sedang yaitu 0,405 .

\section{SIMPULAN}

Mean arterial pressure responden sebagian besar pada kategori tinggi sebanyak 16 responden $(53,3 \%)$. Sebagian besar responden mengalami kejadian mual muntah pasca operasi yaitu sebanyak 19 responden 63,3 \%. Ada hubungan yang signifikan antaramean arterial pressure dengan kejadian mual muntah pasca operasi pada pasien post anestesi spinal di RS Bhayangkara.

\section{DAFTAR PUSTAKA}

BirnbachDJ, Browne IM. 2010. Anesthesia for obstetrics. In: Miller RD. Miller's anesthesia. 6 th. Ed. Pennsylvania: Elsevier Churcill Livingston.

Georg, Maschmeyer. 2015. Infections In Hematology. USA: Springer.

Keat, Sally. 2012. Anaesthesia on the move. Jakarta: indeks.

Kundu. 2017. Mean Arterial Pressure Classification: A Better Tool for Statistical Interpretation of Blood Pressure RelaedRisk Covariates. Cardiology and Angiology: An International Journal;6(1)
Majid, Abdul, Muhammad Juda \& Umi Istianah. (2011). Keperawatan Perioperatif. Yogyakarta: Gosyen Publishin.

Mulroy, Michael F. (2009). A Practical Approach to Regional Anesthesia, 4th ed. Philadelphia: Wolters Kluwer Health.

Nileshwar, Anitha. 2014. Instant Access Anestesiologi. Tanggerang Selatan: Bina. Rupa Aksara.

Novitasari. 2017. Hubungan MAP dengan kejadian PONV pada pasien seksio sesarea dengan spinal anestesi di RSUD Sleman Yogyakarta. Skripsi.

Smith, H.S., Smith, E.J., \&Smith, B.R., 2012. Postoperative nausea and vomiting. Ann Palliat Med, 1(2): 94-102 